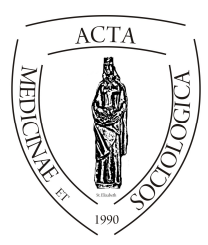

\title{
Az erdélyi magyar szövetkezetek jelenlégi helyzete. Esetpéldák
}

\author{
Csipkés Hajnalka-Szende
}

PhD hallgató, Babeș-Bolyai Tudományegyetem Szociológia Doktori Iskola, 400604 Kolozsvár, 21 Decembrie 1989 sugárút, 128.

\section{INFO}

\begin{abstract}
Hajnalka-Szende Csipkés szende_csipkes@yahoo.com
\end{abstract}

legal framework, producers' behavior, cooperatives, Transylvanian farmers, minorities

\section{Keywords}

\begin{abstract}
The contemporary situation of the Transylvanian Hungarian co-operatives. Instances The author presents in parallels the legal regulatory history of cooperatives in Hungary and Romania and also the legal perspectives of the current systems, highlighting the cooperative behavior of Hungarians in Romania. Existing statistical data is considered as starting-point, according to which both countries are characterized by a low number of cooperatives. As a part of the research, the author presents two case examples and five interviews with Transylvanian farmers in order to reveal the practical barriers to the spread of cooperatives.
\end{abstract}

\begin{tabular}{ll}
\hline Kulcsszavak & Absztrakt. A szerző párhuzamba állítja a szövetkezetek ma- \\
jogszabályok, & gyarországi és romániai szabályozásának jogtörténetét, vala- \\
termelöi magatartás, & mint az aktuális szabályozási rendszert, kiemelve a romániai \\
szövetkezetek, & magyarok szövetkezési magatartását. Kindulási alapul szol- \\
erdélyi termelők, & gálnak azon statisztikai adatok, melyek szerint mindkét or- \\
kisebbségek. & szágban alacsony a szövetkezetek száma. Említésre kerülnek \\
& azon kritikák is, melyekkel a szakirodalom illette az aktuális \\
kelet-európai szabályozási rendszereket. \\
A kutatási részben a szerző két erdélyi magyar érdekelt- \\
ségü szövetkezet esetpéldáját mutatja be és öt, szintén erdélyi \\
magyar termelővel folytatott interjút dolgoz fel.
\end{tabular}

Ez a tanulmány a XI. Nyíregyházi Doktorandusz Konferencián (2017. 12. 01., Nyíregyházi Egyetem) elhangzott előadás alapján készült. 


\section{Bevezetés}

Magyarország és Románia, mint poszt-kommunista államok, szövetkezeti téren hasonló hiányosságokkal küzdenek, annak ellenére, hogy mindkét állam célja az Európai Unió által előirányzott agrárpolitikák megvalósítására.

„A múlt század közepén létrehozott Európai Gazdasági Közösség (Közös Piac) első fejlődési szakaszában (1951-1957) olyan gazdaságpolitikai alapelveket fektettek le, amelyeknek célja az AEÁ életszínvonalának elérése vagy megközelítése volt. Ehhez gazdaságélénkítő stratégiát kellett kidolgozniuk" (Albert-Lőrincz és Albert-Lörincz 2014: 7).

Megjegyzendő, hogy ezen stratégiák különösen az Európai Gazdasági Közösséget (EGK) alapító országok (Belgium, Németország, Franciaország, Olaszország, Luxembourg és Hollandia) (Albert-Lőrincz, 2014) közös agrárpolitika törekvései túlnyomórészt hozzájárultak a jelenlegi jól müködő szövetkezeti modell létrejöttéhez.

Az 1989 előtti diktatórikus rendszerek gazdaságpolitikája (Hunyadi, 2007), valamint az ezt követő hiányos jogi szabályozás következtében, ezekben az országokban drasztikusan lecsökkent a szövetkezetek száma (Simon, 2007). Az utóbbi években viszont, az Európai Uniós integrációs törekvések során, ismét fellendülni látszanak a mezőgazdasági szövetkezeti szerveződések, de a szerveződési folyamat korántsem problémamentes. Annak ellenére, hogy felismerték a szövetkezeti termelés számos előnyét és hasznosságát, mindkét tagállam regionális és vidékfejlesztési problémákkal küzd, beleértve a mezőgazdasági tevékenységeket is (Szabó és Barta, 2014; Szociálpolitikai kiértékelés vidékfejlesztés szempontjából 2014-2020, 2013). A probléma egyrészt a kormányzati szféra nem kielégítő hatékonyságával, illetve a jogi háttér hézagosságával, másrészt a termelők hozzáállásával hozható összefüggésbe. Bár léteznek a szövetkezeti formákat ösztönző kormányzati szintü rendelkezések, ezek nem elég hatékonyak, ugyanakkor a termelök nehezen tudnak megszabadulni azoktól az elöítéletektől, amelyek a szövetkezetekhez kapcsolódó negatív tapasztalataikból táplálkoznak. Annak ellenére, hogy Romániában a mezőgazdasági szövetkezetek száma az elmúlt években növekvő tendenciát mutatott (Barna, 2014), 2014-ben 68 mezőgazdasági termelőszövetkezet létezett Romániában, míg Magyarországon 1116 (Az Európai Mezőgazdasági Szövetkezetek Szövetség jelentése, 2014).

Romániában a mezőgazdasági szövetkezetek mellett más termelői együttműködési formák is léteznek, mint például a termelői csoportok, termelői szerveztek, mezőgazdasági társaságok. A kutatási adatainkból tudjuk, hogy ennek ellenére a gazdák többsége egyetlen jogi müködései formában sem vesz részt. Így adott a kérdés: elég ösztönző lesz-e a beígért adókedvezmény az olyan termelők számára, akik eddig feketén és adómentesen müködtek?

A kérdésre kutatási adataink alapján szeretnénk választ adni.

\section{A kutatás módszertana}

Jelen tanulmány kutatási része két erdélyi magyar érdekeltségü szövetkezet esetpéldáját és öt szintén erdélyi magyar termelővel folytatott interjú összegzését dolgozza fel. A 
kutatás célja az volt, hogy fényt derítsen a szövetkezetek terjedésének akadályaira. Azon feltevésünket, hogy a szövetkezetek terjedése Romániában nehézkes, problematikus statisztikai adatokra, valamint a szakirodalomban jelzettekre alapoztuk.

Az esetpéldák által egy megbukott és egy jelenleg is müködő szövetkezeti kezdeményezést mutatunk be, felhasználva a rájuk vonatkozó sajtóinformációkat. Az esetpéldákból kiderül, hogy milyen gyakorlati problémákkal állnak szembe a szövetkezetek.

Az interjúk során a termelők és a gazdák azon belső indíttatásait igyekeztünk felszínre hozni, amelyek következtében alacsony a szövetkezetekbe való társulási hajlandóságuk. Öt személyt kérdeztünk meg a Kolozs megyei Várfalva községböl, ahol a lakosság többsége hagyományosan mezőgazdasággal foglalkozik. Adatgyüjtésre kötetlen interjút választottunk annak reményében, hogy a termelök szabadon fognak beszélni az őket foglalkoztató problémákról, félelmeikröl.

\section{Esetpéldák a romániai magyar agrárszövetkezetek helyzetére vonatkozóan}

Az alábbiakban két romániai magyar érdekeltségü szövetkezet esetpéldáját mutatjuk be. 2006-ban alapult az Aranyoskert szövetkezet, mely az aranyosszéki (Kolozs megye, Torda környéke) magyar gazdák jobb érvényesülését kívánta elösegíteni. Legfontosabb céljuk a termékek hatékonyabb értékesítése volt. Ennek érdekében termésnapokat, terménykiállításokat szerveztek, de mint utólag kiderült, a kezdeményezések nem voltak kellően népszerüsítve. A terv azért sem müködött, mivel Romániában a 2007-es Európai Uniós csatlakozás nem hozta meg a remélt változásokat a mezőgazdasági termények értékesítése terén. A szövetkezet által biztosított felvásárlási árak alatta maradtak a piaci áraknak. Az Aranyoskert szövetkezet a tagjaitól a viszonteladói ár alatt tudta volna átvenni a megtermelt zöldségeket, így a gazdák a szövetkezeten kívüli direkt értékesítést választották. Ezáltal a szövetkezés eszmeisége is sérült. Az Aranyoskert esetén a kezdeményezés igénye nem közvetlenül a termelők részéről fogalmazódott meg, ami rontotta az esélyeket.

A bukás további oka az volt, hogy túl kevés, mindössze 90 termelőt sikerült bevonni. A szövetkezet tevékenységeit először lefagyasztották, végül feloszlatták (Makkay, 2013).

Ellenpéldaként említjük a jelenleg is müködő Nagyküküllő Mezőgazdasági Szövetkezetet, amely 2011 februárjában alakult Hargita megye Székelykeresztúr városában. Hatszáz helyi tejtermelö családot tömörít, akik egyben szövetkezeti tagok és tulajdonosok. Megvalósítása egymillió euró értékü befektetést igényelt. A szövetkezet egy modern tejfeldolgozót üzemeltet és tejtermékek széles palettáját kínálja. (Hargita TV beszámoló, 2013; Székelytermékek honlapja, 2015). A szövetkezet elnöke egy napilapban adott interjúban megemlíti, hogy a kialakult gazdasági helyzet következtében vált lehetővé az összefogás: 2010-ben bezárt a régi tejüzem, értékesítési lehetőség nélkül hagyva a helyi gazdákat. Akkoriban nem a szövetkezeti gondolatba vetett meggyőződés, hanem a kényszerhelyzet eredményezte a társulást. A kezdeményezés első éveiben a tejüzem majdnem csődhelyzetbe került, még banki hitelhez is folya- 
modott. A 2013-as évet veszteséggel, viszont a 2014-es évet a tejüzem már nyereséggel zárta. Kezdetben a gazdák bizalmatlanok voltak, féltek az újtól, leginkább a kevéssel piaci ár fölött kínált literenkénti összeg motiválta öket. Gondolkodásmódjukat befolyásolták a kommunizmus ideje alatt szerzett negatív tapasztalatok valamint a közösségi élet elsorvadása. A szövetkezetbe vetett bizalom lassan és nehézkesen épült fel. Annak ellenére, hogy a szövetkezeti tevékenység gondokat vet fel, egyre több erőforrással tudnak közép- és hosszú-távú tervekre összpontosítani. A szövetkezet elnöke szerint a gazdák kezdik magukénak érezni a kezdeményezést, érdekli öket a tejüzem müködése, nagy számban vesznek részt a számukra szervezett üzemlátogatásokon. Napjainkra a társultak megtapasztalhattak néhányat a szövetkezeti előnyökböl. A szövetkezet elnöke bízik a jövőben és a kezdeményezés megerősödésében, szerinte lehet számítani a gazdák támogatására is (Domján, 2015).

\section{A szövetkezetek megítélése a gazdák véleménye alapján}

A romániai kistermelők jelenleg is általánosságban elutasító magatartást tanúsítanak a termelői csoportokba való szerveződés iránt. Kutatásunk során egy mezőgazdasági termelői hagyományokkal rendelkező térség, az esetpéldából már ismert Aranyoskert szövetkezeti kezdeményezés térségében - Kolozs megye, Torda környéke - kistermelővel beszélgettünk. Mind az öt megkérdezett interjúalany családjában több személy foglalkozik a mezőgazdasággal, nagyrészt feketén értékesítik terményeiket, bár közülük ketten igényeltek már a közelmúltban termelői támogatásokat. Bár kutatásunk nem tüzte ki célul a támogatási rendszerek felmérését, a gazdákkal folytatott kötetlen interjúk során néhány gyakorlati probléma mégis szóba került. A gazdákat a szövetkezeti kérdések egyáltalán nem foglalkoztatják, inkább az egyénileg igényelhető támogatásokra összpontosítanak. Azáltalunk vizsgált településen nem szokványos a támogatások igénylése sem. Nagy hatással volt a térség gazdáira az Aranyoskert szövetkezeti kezdeményezés kapcsán megélt kudarc, valamint a kommunizmus idején szerzett negatív tapasztalatok is. A történetből nem a tanúságok maradtak meg, hanem amint az interjúkból kiderült, a legtöbben a kommunista termelőszövetkezetet látták ismét megtestesülni és elbukni. Jelenleg bármilyen kontextusban merülne fel a szövetkezet gondolata, a sikertelenségét megélve mindenki legelőször az Aranyoskert negatív példáját hozza fel eleve elzárkózva bárminemü együttmüködéstől. A szövetkezetekkel kapcsolatosan is általánosan megfogalmazódott, hogy a gazdák sem jószágot, sem ingatlant „,be nem adnának a közösbe”, mert félnek attól, hogy ismét elveszik tölük.

A negatív tapasztalathoz társulnak a mindennapokban megélt nehézségek, például az, hogy a termelési folyamatok sokszor nem gépesítettek, ezért a termelök nehéz fizikai munkát kénytelenek végezni. Nincs minden gazdaságnál traktor, szántó-, vető-, permetező- és arató-gép, ezen szolgáltatásokat a kevésbé módos termelők bérlik, ami növeli a termelési költségeket.

Arra a kérdésre, hogy hol értékesítik a helyi termelök a terményeiket, azt a választ kaptuk, hogy a legtöbben jobbnak látják, ha saját maguk végzik az értékesítést a pia- 
cokon. A gazdák is tudják, hogy nem igazán kifizetődő a lehetőségeik szerinti termelés. A terményeket nemcsak a helyi piacokra viszik, hanem sokszor több száz kilométerre is, annak függvényében, hogy a szóbeszéd szerint melyik piacon kapnának jobb árat. Azon termelőknek, akinek nincs saját gépkocsija, egyénileg vagy társulva fizetnek a szállításért. Ebből adódóan kialakult egy olyan réteg a faluban, akik foglalkozásszerüen szállításból élnek vagy ezzel egészítik ki a jövedelmeiket. A termények értékesítése a megcélzott piacokon a kereslet függvényében akár hét napig is eltarthat, ez idő alatt az árulást végző személy szállásbérletet fizet a piac környékén. Télen sokszor napokig fedetlen, jobb esetben gyengén szigetelt, de többnyire fütetlen piacokon kénytelenek árulni. Aki a nagyobb mennyiségben megtermelt zöldségtől szeretne szabadulni, kénytelen jóval olcsóbban viszonteladóknak átadni a terményét. Arra is volt példa, hogy bizonyos terményeket nyomott áron átvettek helyi üzletek, majd nagy haszonkulccsal értékesítették az úgymond feketén beszerzett zöldségeket.

A termelési folyamat, valamint az értékesítéssel járó „piacolás” egy család teljes évi idejét igénybe veszi. A termelö-gazdák hatalmas erőfeszítésekkel mindössze a minimális megélhetést tudják biztosítani családjaiknak. A válaszadók szerint a legnagyobb erőfeszítések árán is csak a termelői támogatások igénybevétele nélkül, nagyjából az egész évi termelési folyamatokkal járó önköltségi szintet lehet elérni. A körülmények ellenére mégsem hajlandóak változtatni, bár a gazdák szerint sem „éri meg" a tevékenység. Válaszukat azzal indokolják, hogy elődeik is így éltek, és ha nekik elég volt, most, ill. a jövőben is elég kell, hogy legyen. Az utóbbi évtizedben a helyzet még nehezebbé vált a nagy bevásárlóközpontok elterjedése után. A mezőgazdasági kistermelök közvetlenül a rendszerváltás után sokkal jobban éltek, munkájukat a piac jobban értékelte. A nagy bevásárlóközpontokban és áruházakban megjelent külföldi termékekkel viszont nem tudnak árban versenyezni. A gazdák az Európai Uniót hibáztatják, hogy lehetővé vált a nyomott áron kínált külföldi termékek nagytételben történő árusítása, ami számukra kedvezőtlen. Szinte csodavárásként bíznak abban, hogy változni fog a helyzet és jobbra fordul a sorsuk, de érdemben kevesen tesznek érte. A helyzetet némileg ellensúlyoznák a különböző pótlékok - amennyiben könynyen és átláthatóan lehetne igényelni őket. Azonban ezeknek az igénybevételére nincsenek felkészülve a gazdák, információik hiányosak. Azon megkérdezett személyek, akik már igényeltek kis összegü Európai alapú támogatásokat (ketten az öt interjú alanyból), a támogatások hozzáférhetőségére panaszkodtak. Egyikük formai és közigazgatási nehézségek miatt a támogatásnak csak az első részét tudta lehívni. A megkérdezettek arra is felhívták a figyelmünket, hogy tudnak olyan esetröl is, amikor a támogatást igénylő gazda eleve úgy pályázott, hogy eleve nem állt szándékában az elöírt növekedést megvalósítani, beérve a részleges támogatással. Interjú-alanyaink arról is említést tettek, hogy a hatóságok túl mereven ragaszkodnak a pályázatok alapjául szolgáló üzleti tervekhez, amelyek eleve becsült értékeket tartalmaznak - így az ellenőrzést követően veszélybe kerülhet a további kifizetés. Előfordult, hogy nem vették figyelembe, hogy a takarmány- ill. állatállomány folyamatosan változik a termelési körülmények illetve a jószágok születési arányának függvényében. Nehezményezték, hogy a hatóságok nem segítik a támogatásokat megpályázókat, bármilyen kérdést illetően a hivatalos válaszokban csak az amúgy is zavaros normákat idézték, érdemleges értelmezésre nem lehet számítani. További gondot jelent az információ 
hiánya, a pályázati kiírásokat közvetlenül a projekt kezdete előtt is módosítgatják, így többször át kell írni vagy újraszámolni az igényléseket.

Arra a kérdésünkre, hogy szövetkezeti formában vajon nem tudnának-e hatékonyabban pályázni, mind az öt megkérdezett gazda azt mondta, hogy bár hallott róla, ők félnének közösködni, nem bíznak a többi termelöben, így inkább egyénileg próbálnak boldogulni.

Azon három megkérdezett gazda, aki soha nem is pályázott arról beszélt, hogy félnek támogatásokat lehívni, egyrészt mert nem rendelkeznek a müködésüknek keretet adó jogi formával, másrészt attól félnek nehogy vissza kelljen fizetni a támogatás összegét, esetleg még a földjeiket is elveszíthetik. A megszerzett információk olvasatunk szerint arról tanúskodnak, hogy nem elég tájékozottak a gazdák, téveszmék miatt szük látókörüek és annyira lefoglalja őket a mindennapi megélhetés megteremtése, hogy kísérletezni senkinek sincs kedve. Az interjúk során fény derült arra is, hogy vannak olyan személyek, akik eleve úgy vélik, hogy a támogatásokhoz „,befolyásosnak kell lenni”, kapcsolatok nélkül nem férhetnek hozzá, ezért nem is próbálkoznak.

\section{Következtetések}

A kutatás során megkérdezett gazdák úgy ítélték meg, hogy az Európai Uniós csatlakozás előtt kifizetődőbb volt mezőgazdasággal foglalkozni, mint manapság, amikor támogatások nélkül jó, ha az önfenntartó jövedelmi szint elérhetö.

Az esetpéldákból arra következtethetünk, hogy a társulás eszméje is távoli a megkérdezett gazdák számára. Szükséges lenne a mentalitásbeli váltás és a fejlődés lehetôségeire vonatkozó információkkal való felvértezés. Az Európai Uniós támogatások hatékonyabb lehívhatósága szövetkezeti formában nem elegendően motiváló, túlságosan távlatinak érzik a kistermelők. A gyakran változó és nem átlátható jogi háttérnek is eltántorító hatása van.

Megállapítható, hogy a kommunizmus évtizedei alatt az önkéntes társadalmi öszszefogáson alapuló konstruktív tradíciókat gyakorlatilag tönkretették (Erdős, Juhász, 49), mint például a termelök, gazdák és kereskedők kölcsönös segítségnyújtási mechanizmusait. Ennek következtében jelenleg a szövetkezet gondolata még nem lépett ki a kommunizmus alatt hozzá társított negatív tapasztalatok árnyékából, az érintett gazdák nem látják a lehetséges előnyöket vagy eleve nem bíznak abban, ami közös, illetve közösségi tevékenységen, feladat- és hatáskörmegosztáson alapszik.

Szükség mutatkozik azon civil szervezetek támogató és a mentalitás megváltoztatását célzó munkájára, amelyek a falvak életminőségének javítását felvállalják.

Ugyancsak célszerü a szövetkezés és az érdekszövetségek eszmei és gyakorlati vetületeinek további kutatása hazai és nemzetközi színtéren egyaránt. Juhász $(2006,14)$ tárgykörben folytatott kutatásaiban Commons iránymutatásai alapján rámutat, hogy az érdekszövetségek közül a mezőgazdasági, illetve farmerszervezetek és a szövetkezetek játszanak a szakszervezetek mellett jelentős szerepet a demokrácia megszilárdításában, mint fontos társadalmi intézmények.

Albert-Lőrincz (2017: 82) „szerint a poszt-kommunista országok egyfelől szeretnének minél gyorsabban fölzárkózni legalább az európai standard elfogadható legalsó 
szintjére, másrészt mindegyre a korábbi örökség gáncsába ütköznek. A helyzetet nehezíti ezen országok szükös pénzügyi helyzete, az állami tulajdonú tervgazdaság átalakítása a magántulajdon alapú piacgazdaságra, a gyengén müködő gazdaság, az infláció, a munkanélküliség, az új szociális problémák, a politikai érdekek, a demográfiai (etnikai, elöregedés, lecsökkent születési ráta, migráció és emigráció) sajátosságok, társadalmi feszültségek, az uniós elvárásoknak megfelelés és az ezekből adódó feszültségek, a kommunizmus öröksége."

\section{Irodalomjegyzék}

1. Albert-Lörincz, Cs. (2014): Diminishing national sovereignty affecting EU member states' citizenship? Globalization and Intercultural Dialogue. Multidisciplinary Perspectives. ARHIPELAG XXI PRESS.

http://www.upm.ro/gidni/GIDNI-01/GIDNI\%2001\%20-\%20Law.pdf, (letöltés időpontja 2017 november 17)

2. Albert-Lőrincz M., Albert-Lörincz Cs. (2014): Kifelé a multikulturális térbe. Magiszter, XII. évfolyam, 3. szám, 6-15. ISSN 1583-6436.

3. Albert-Lörincz, Cs. (2017): Szociálpolitikai alapok és a jóléti perspektívák térvesztése. Kolozsvári Egyetemi Kiadó.

4. Az Európai Mezőgazdasági Szövetkezetek Szövetségének jelentése. (2014): Development of agricultural cooperatives in the EU 2014.

http://www.europarl.europa.eu/meetdocs/2014_2019/documents/agri/dv/copacogecareport /copa-cogecareport_en.pdf, (letöltés időpontja 2017. november 17.)

5. Barna, C. (2014): Atlasul economiei sociale (A szociális gazdaság feltérképezése Romániára vonatkozóan). Institutul de Economie Socială. http://www.ies.org.ro/library/files/atlas.pdf, (letöltés időpontja 2017 november 17)

6. Domján, L. (2015): Beszélgetés Bálint Sándorral, a Nagy-Küküllő Mezőgazdasági Szövetkezet Elnökével,

Hargita Népe online napilap. (2015):

http://hargitanepe.eu/beszelgetes-balint-sandorral-a-nagy-kukullomezogazdasagi-szovetkezet-elnokevel/, (letöltés időpontja 2017. november 17.)

7. Erdős Bognárné M., Juhász G. (2011): Shaping volunteer-friendly organizations in Hungary, Humán Innovációs Szemle, 2:(2) 52-66, 2011. http://humanexchange.hu/site/uploads/HISZ_II2_46-59.pdf, (letöltés időpontja 2017. november 17.)

8. Juhász G. (2006): Társadalmi és munkaeröpiaci érdekek - civil szerepek, Human Exchange Alapítvány, Kaposvár, (pp. 112.).

9. Hargita TV beszámoló. (2013): http://hargitatv.ro/2013/orszagos-premiernekszamit-a-letrehozott-tejfeldolgozo-uzem/, (letöltés időpontja 2017. november 17.)

10. Hunyadi, A. (2007): A különböző szövetkezeti típusok és a szövetkezeti értékrend kialakulása. In: Sómai, J. (ed.) Szövetkezetek Erdélyben és Európában. Kolozsvár: Romániai Magyar Közgazdász Társaság.

11. Makkay, J. (2013): Aranyosszéki szövetkezet: utópia vagy szükséglet? Erdélyi Napló. 
http://www.erdelyinaplo.ro/gazdasag/aranyosszeki_szovetkezet_utopia_vagy_s zukseglet, (letöltés időpontja 2017. november 17.)

12. Mezőgazdasági és Vidékfejlesztési Minisztérium. (2013): Analiza socioeconomică în perspectiva dezvoltării rurale 2014-2020 (Szociálpolitikai kiértékelés vidékfejlesztés szempontjából 2014-2020). http://eufinantare.info/docs /analiza-dezvoltarii-rurale-agricultura-iulie-2013.pdf, (letöltés időpontja 2017. november 17.)

13. Simon, S., (2007): A romániai szövetkezeti törvény és az európai uniós gyakorlat. In: Sómai, J. (ed.) Szövetkezetek Erdélyben és Európában. Kolozsvár: Romániai Magyar Közgazdász Társaság.

14. Székelytermékek honlapja. (2015):

http://www.szekelytermek.ro/?1=hu\&m=nagykukullo-mezogazdasagi-

szovetkezet,

(letöltés időpontja 2017. november 17.) 